\title{
CHANGING SOCIAL STATUS OF PENSIONERS AND THE PROSPECTS OF PENSION REFORM IN THE CZECH REPUBLIC ${ }^{1)}$
}

\author{
Jiří Večerník*
}

\begin{abstract}
:
The changing social status of pensioners is described and structured according to stylized periods. First, I identify the salient features of the communist regime that shifted pensioners to the margins of society. Second, I attempt to trace how the position of pensioners changed as a result of the democratic transition, which empowered pensioners as voters and which led to their rising relative income. Third, I review the recent debate about pension reform - which, as an unresolved issue, has entailed the maintenance of the status quo - and pensioners' swing towards the left. Fourth, the possible impact of current reform proposals on the future income of pensioners are considered. In conclusion, the importance of bringing children back into the pension system and increasing the activity rate of older persons are stressed.
\end{abstract}

Keywords: pensioners, pension system, pension reform, Czech Republic

JEL Classification: H56, D31

Explicitly, the debate is about the pension system but only implicitly about pensioners. How are they regarding their social status? How much do they have to be defined by their current position - age and economic inactivity - and how much by their emeritus status - education, former occupation and related earnings? The fo-

\footnotetext{
*) Institute of Sociology, Academy of Sciences of Czech Republic, Jilská 1, CZ - 11000 Praha 1 (jiri.vecernik@soc.cas.cz).

1) This study was supported by the grant of the Grant Agency of the Czech Republic 403/03/0339 "Adjustment of Socioeconomic Values in the EU Accession Process". Thanks are due to Jiří Král, Director of the Department of Social Insurance of the Ministry of Labour and Social Affairs, and Vladimír Bezděk, economist of the Czech National Bank for precious comments and suggestions.
} 
cus is on pension benefits that are personal source of income but pensioners' standard of living depends on households they live in, accumulated wealth, and also the amount of voluntary intergenerational cooperation.

European nations are currently facing the declining numbers of children and increasing life expectancy, and cumulatively these trends result in the ageing of the population which is a threat for economic performance and welfare burden. As the system dependency ratio - i.e. the ratio of those requiring benefits in old age to those who are in employment and therefore treated as contributors - worsens, the pressure on pension system grows. The task is twofold: to keep the system sustainable and simultaneously to guarantee a decent standard of living for pensioners. There is no single "best" pension system and the only solution is to engage a variety of resour= ces.

A systemic reform of pension scheme towards a greater engagement of individuals presents sizeable challenge for politicians who are anxious about voters' support. Due to ageing, the percentage of old constituency is increasing and its importance is growing also due to the fact that older people use to be more reliable voters regarding their participation in elections. The short span of democratic mandate gives always priority to short-time "tactic" decisions before long view "strategic" decisions. Today's pensioners are more important for politicians than tomorrow's pensioners also because only the former ones know their benefits exactly and are able to exchange them into ballots.

To explain the situation, there can be offered here a historical perspective aiming to identify the position of pensioners and its changes. First, we reveal the salient features of the communist regime, which shifted pensioners to the margins of the society. Second, we attempt to follow the change related to the transition, which empowered pensioners as voters with presumable impact on their relative standard of living. Third, we appraise the current pension reform debate and possible effect of variants on future position of pensioners. In conclusion, possible effects of current reform proposals will be considered and individual actors and their activities in the process observed.

\section{The Communist Regime: Pensioners as the Poor}

One of the main catchphrases of the socialist revolution in former Czechoslovakia was "He who does not work should not eat!" Immediately after 1945, this slogan was applied by the Communist Party to prominent capitalists and property owners. Later, it served to encourage the legalization of work duty and the persecution of alleged "social parasites". It also provided, albeit implicitly, a rationale for neglecting pensioners and their benefits. After 1948 almost no earnings-relation formulae were applied. In 1957, a formula was formally applied, but in 1964 again suppressed. The most important source of disparities was pensioner categories defined by previous occupation, not to speak about "personal pensions" for members of the communist elite. ${ }^{2)}$

2) The highest of the three categories comprised, for example, miners, army officers, policemen and pilots. The so-called "personal pensions" were assigned not only to top politicians, but also to prominent artists and sportsmen awarded national prizes. 
Not disparities but equality was the goal, however. In seeking to bring about equality among people the communist regime tried to reduce everyone to the common denominator of the working class. It also downgraded pensioners as a whole. In a sense, it even established the "social category of pensioners". Marxist doctrine allowed only the (ruling) working class, (socialist) intelligentsia and (cooperative) farmers as elements of the social structure, but a fourth social group - that of pensioners - emerges in statistical and political analysis. It is defined by the specificity of its treatment and, in this connection, a certain standard of living. While the link between previous earnings and the level of pension benefits was in fact removed, considerable disparities in benefits appeared according to pensioner age: the older the pensioner was, the less was his or her "right to eat".

Instead of regular valorisation, the communist state bestowed on its citizens irregular "gifts", couched in the paternalistic rhetoric of the "benevolent ruler". In fact, however, social protection had the lowest priority in state spending, falling far below the army and police, industry and agriculture, the party and state bureaucracy. Social security was praised as pre-eminent among "socialist advantages", but the provisions afforded were in fact a residual part of state expenditure. As compensation the state generously allowed pensioners to stay in employment and earn an extra income to supplement their modest benefits.

Formally, the system appears to have been a balanced mixture of the systems of Bismarck and Beveridge. In reality, though, it was a perverse revision of both. The work-related basis and the rationale of ensuring loyalty to the state in exchange for old-age security were adopted from the Bismarckian system. This system had been the basis of the Austrian social security system. It was introduced to the Czech territories in the 1880s and continued to operate in the inter-war Czechoslovak Republic. Meanwhile the state's responsibility to provide minimum provision was adopted from Beveridge. Implicitly, all pensioners were thus treated as poor citizens without means and therefore embraced by the state's care, as in the residual type of welfare regime.

In spite of this, the gap between wages and pension benefits was small under the communist regime. The reason was that, in principle, the social status of both current and former employees had the same - political - roots. Each was derived from the totalitarian regime, the functioning of which was embodied in the dominant "need" principle, as opposed to the "market" principle (Večerník, 1999). Employees were not rewarded with differentiated, market-set income for their participation in the labour market, and pensioners were not provided for according to their previous earnings and related contributions. Not uneven merit, but uneven needs served as the rationale for disparities of income. More important disparities in income were created by the returns from loyalty and political position.

In the last decades of the communist rule, the gap between per capita income level of pensioners' household (if considering only those without economically active members) and the population average has substantially diminished: from $31 \%$ in 1970 to $26 \%$ in 1980 and to $20 \%$ in 1988 (Facts, 1997). Also the ratio of pension benefits to gross wage has improved up to $64 \%$ in 1989 . Nevertheless, the poverty rate of pensioners according to the official subsistence minimum amounted to $8.5 \%$ in comparison with $2.7 \%$ on the average and the poverty rate according to current 
EU measure (based on much flatter equivalence scale) was even $36.6 \%$ against $7.5 \%$ on the average (Microcensus surveys, own computations).

When comparing pension benefits with the average wage and pensioners' incomes with the average figures, we have to bear in mind the generally low purchasing power of household incomes. Not pension benefits were so high but wages were so low, conforming to the "need principle" of the communist regime, however attenuated during the last two decades showing its "human face" in consumption, after turning it away in civic freedoms (Večerník, 1999). In fact, financial limits inhibited pensioners to renew their wardrobe, not to speak about some update of household equipment and budget discretion for leisure and recreation. Also due to low costs of housing, the most of pensioner households' budgets was spent for food: $57 \%$ in $1970,45 \%$ in 1990 (Facts, 1997).

\section{The Transition to Democracy: Pensioners as a Constituency}

In 1990, a radical change in the economic system began to take place: state ownership of production assets was dismantled, formerly distorted prices adjusted, and significant sectors of the economy opened up to market forces. Parallel to this, only to a lesser degree, the social security system began to adjust to the new conditions. Due to valorisation of pension benefits, the pension/wage the ratio saw a substantial improvement up to 1992 (Figure 1). In consequence, a massive movement of pensioners to the lower-middle income categories was registered by income surveys for the period 1988-1992 (Večerník, 1999).

Figure 1

Average Old-Age Pension Benefit in \% of the Average Wage

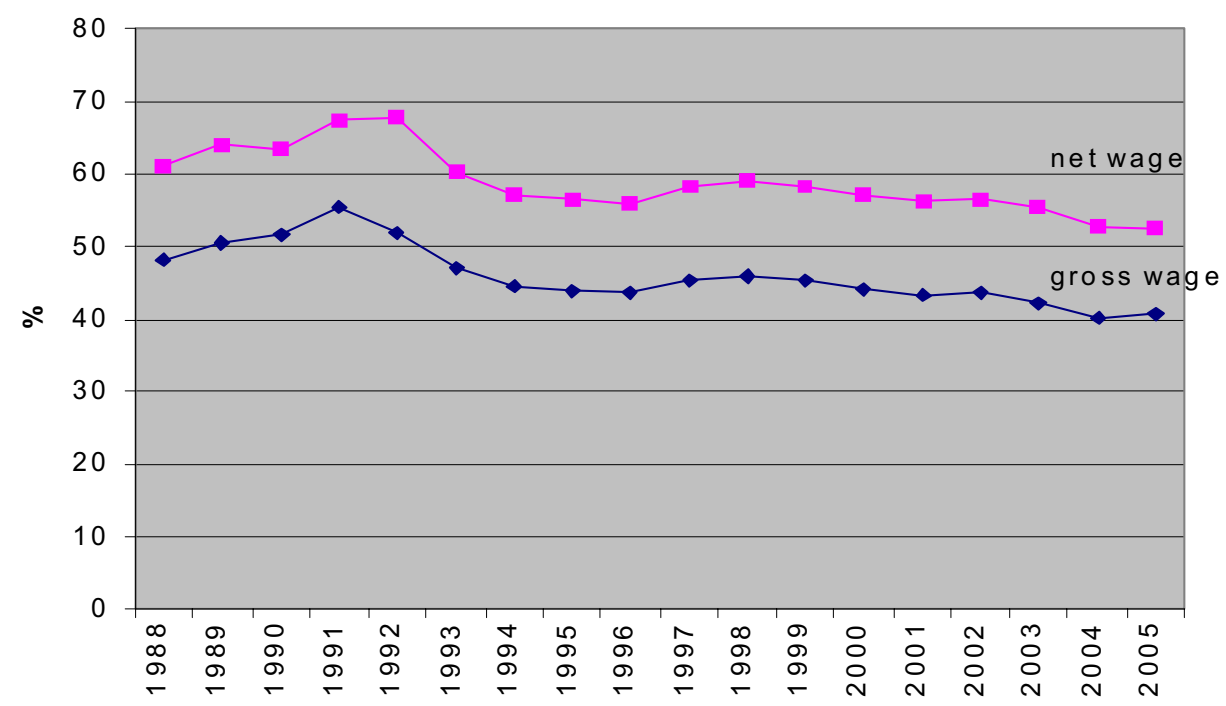

On the other side, income of pensioners' households decreased since the most of working pensioners were pushed out of the labour force under pressure from 
employers and in response to - temporarily applied - heavy taxation of any earnings taken in tandem with pension benefits. Although rather involuntary, the already quite levelled pension benefits were further (but this time positively) equalized through several measures. First, the so-called "personal pensions" for members of the nomenklatura, top sportsmen and artists were removed. Second, the categorization of pensioners into three classes according to the importance of their occupations to the regime was eliminated. And third, the new valorisation scheme aimed to reduce disparities between pensions assigned at different times.

Czech economic reform has not explicitly addressed income inequality of households, nor has it directly been able to. Nevertheless, various measures were introduced which caused shifts on the income ladder to the favour of pensioners and disfavour of families - valorising pension benefits while reducing family allowances. In terms of EU risk-of-poverty measurement, poverty of pensioners has decreased from 32\% in 1988 to 5\% in 2002 (Večerník, 2004). No reason for a change in the status of pensioners has been explicitly offered, but we can speculate on the implicit growing regard for pensioners as voters. When the purely formal elections held under the communist regime were replaced by truly democratic elections under new political regime, the importance of pensioners as citizens increased dramatically.

The new economic regime, however, was unlikely to receive a warm welcome from pensioners. They had already left the labour market, and could therefore hardly expect a really significant increase in their standard of living. Indeed, the liberal rhetoric predominant at the time must have caused them concern over their future subsistence. Most pensioners had spent their middle age under the communist regime and many of them had enjoyed successful careers. There were, of course, also quite adverse situations of people persecuted or simply just not allowed to study and find a decent job because of the lack of manifested loyalty to the regime.

While the first free elections in 1990 were in fact a plebiscite for democracy in which the Civic Movement $(\mathrm{OH})$ won two-thirds of the vote, the second, 1992 elections were a "real" democratic competition in which 20 political parties participated. In these elections one in five voters was pensioner. Consequently, no political party failed to stress its commitment to pensioners in its election programme. It was expected that pensioners would sympathize more with the political left, especially the post-communist Left Block (LB), and the political centre, represented by the Christian Democrats (KDU-ČSL). However, the two right-wing parties, the Civic Democratic Party (ODS) and the Civic Democratic Alliance (ODA), eventually obtained roughly the same number of pensioners' votes (Table 1).

Against expectations, pensioners have not overwhelmingly supported leftist parties, in spite of the light preference for the Left Block. A bit more, Christian Democrats were preferred as a typical party for older, countryside and catholic-oriented population. However, pensioners did not even strongly support what could be called "their own" party, the Movement of Pensioners for Social Security: the party received a mere $4 \%$ of the total vote and 13\% of all pensioners' votes in the 1992 elections. The elections were won by ODS, also with huge support of pensioners, and it established a coalition government together with ODA and KDU-ČSL.

The new orientation in social security was proclaimed by the ODS as a shift away from the paternalistic welfare state and universal provisions towards an effi- 
cient and targeted welfare policy. However, the party was not interested in withdrawing pension-based access to state revenue and opposed requests from ČSSD and the trade unions for a public pension fund that would capitalize on the current surplus of contributions. ${ }^{3)}$ Unlike Hungary and Poland, the World Bank leverage was not that strong in the Czech Republic and foreign experts were generally not welcomed by leading ODS politicians. In any case, no radical reform introducing a fully-funded system was seriously considered at that time. ${ }^{4)}$

Nevertheless, a clear intention to distribute the risk was incorporated into a twotier project of ODS involving a PAYG basic pension and a state-contributory type of supplementary pension insurance. The basic pension itself was conceived as a combination of two components. One of these was fixed at what was considered to be a guaranteed minimum and the other was variable and earnings-related. The rate of the basic pension as a whole was to shrink and finally settle at only $40 \%$ of the average wage, while the earnings-related component was to increase. In spite of huge trade union pressure, no occupational pension scheme was included in this project, as ODS argued it would be an infringement of the "civic" principle. ${ }^{5)}$ But to appease the trade unions and to preserve the coalition between ODS and KDUČSL, the conditions relating to early retirement were relaxed.

Facing a worsening system dependency ratio, the retirement age was intended to gradually rise. Left-wing opposition parties disapproved of this, arguing that the dependency ratio would in fact worsen later than expected. The proposal provoked a 25,000-strong manifestation in March 1995. The "Pension Insurance Act", one of the most controversial bills passed by Parliament since 1990, was eventually approved, late at night, on the last day of the parliamentary session in June 1995, with the coalition Christian Democrats abstaining and replaced in the vote by a non-governing Czech-Moravian Centre Union Party (ČMUS). The Christian Democrats together with opposition Social Democrats proposed the immediate revocation of the Act (Polívka, 1998).

Since 1994, supplementary pension insurance scheme was introduced that enabled citizens to insure themselves with commercial insurance companies, with the assistance of a state contribution. For this purpose, special licensed and controlled pension funds were established. It was supposed that a supplementary, fully-funded pension scheme would expand to compensate for the expected reduction in the basic pension, thus ensuring equivalence between payments and benefits, and strengthening income disparities between pensioners. There was a lot of wishful thinking in expectations that people will privately save more for their old age and that they are ready to reduce their expectations from the state. Yet other possibility has appeared in private life insurance, partially tax deductible and often completed by employers

3) However, a special account was established within the state revenue in 1996.

4) In fact, the preparation of Czech reform was under way before the crucial World Bank document (World Bank, 1994) was released. The generally liberal orientation was common to both, although the implementation of principles in the Czech Republic was far from thorough.

5) Firms were able to support their employees, in accordance with their profit margin, only by using the services of private insurance companies. 
Nevertheless, the situation differed substantially from that in which reform took place in other countries. The number of pensioners rose only slightly up to 1997 in the Czech Republic (by 4\% only), unlike e.g. Poland where it increased from 5.42 to 7.23 million between 1990 and 1999, i.e. by one-third (ILO, 2002:106) or Hungary where it increased from 2.5 to 3 million between 1990 and 1996, i.e. by one-fifth (Müller 1999:64). Not such a generous replacement rates were introduced as in Hungary ( $75 \%$ of the average wage in the best five years of employment) what also led to growing financial burden. The overall balance of income and expenditures on the (still imaginary) pension bill remained very positive in the Czech Republic.

\section{The Later (non)Reform: Pensioners as Captives}

The outcome of the first "weak reform" of the pension system revealed the ambivalent position of the "liberal" party ODS. It promoted individual responsibility and fuelled the rhetoric on mandatory private old-age insurance. In reality, however, and against all advice that they use the yields from privatization to establish private or public pension funds, the ODS-led government made no resources or funds available for the introduction of pension funds and utilized the entire pension surplus to balance the state budget. It was the small coalition party, ODA, that insisted on earmarking collected contributions as the first step and elaborated a radical pension reform involving the introduction of a second, fully-funded pillar - this, however, remained nothing more than an idea.

The swan song of the ODS-led government was the report prepared by the Ministry of Labour and Social Affairs (MoLSA hereafter) called "Possibilities for Changes in the System of Pension Insurance and Its Financing”. It proposed a basic pension benefit with two components as the first pillar (a fixed-rate component and an earnings-related component, each comprising about $15 \%$ of gross average earnings), and a compulsory old-age private savings scheme as the second pillar (comprising another 15\%). Altogether the system would provide about $45 \%$ of the average wage in pension benefits. In addition, voluntary private insurance already in existence would ensure both that benefits are differentiated and earnings related. This proposed system thus closely adhered to the suggestions that had been made by the World Bank (World Bank, 1994).

Under the interim right-centrist government of Josef Tošovský, the minister of labour and social affairs, Stanislav Volák, proposed the introduction of radical reform. In 1997, the Czechoslovak Commercial Bank (ČSOB) prepared a review of experiences in various countries. The resulting study confirmed the need for radical reform, but offered no clear policy recommendations (Kočišová et al., 1997). The Czech National Bank conducted a study showing that, when combined, an increase in the retirement age and a voluntary, partial contracting-out from the PAYG would make the pension system less redistributive and thus more sustainable in the long run (Bezděk, 2000).

In opposition, the Social Democrats objected to the introduction of changes to the system and demanded guarantee of 50\% replacement rate of gross wage (Hiršl, 1997). They also abandoned their efforts to have the retirement age lowered. After taking office in 1998, ČSSD politicians again explicitly rejected any radical pension reform and announced only parametric adjustments to the current PAYG system 
along with a proposal for public social insurance. They persisted in this despite several important changes that occurred in the late 1990s, which considerably altered the circumstances under which previous pension reforms had been implemented:

- The system dependency ratio, which looked favourable at the beginning of the 1990s, worsened and the demographic forecast had to be re-evaluated.

- The balance of pension revenue and expenditure that was positive until 1996 became negative, and the risk of a rapid increase in the budget deficit emerged.

- As a result of the relaxed, limited restrictions on early retirement, the number of retirees grew considerably and the proportion of early retirees came to equal one half of the total.

- Supplementary private insurance was less popular than had been expected, particularly with regard to the level of payments, which in 1999 fell below $2.4 \%$ of the average wage.

- After the privatization of the last banks, state-supported high employment evaporated and rising unemployment reduced the social security contributions.

Starting in 1998 the Czech political scene was afflicted for four years by the cool truce produced by the "opposition treaty" between the two main parties on the left and the right. Questions about pension reform surfaced on both sides of the political spectrum, but with different views: parametrical "weak" reform or systemic "radical" reform. The two competing approaches were: 1. the proposal of the MoLSA (Concept 2000) that rejected compulsory private insurance and suggested parametric reform involving an actuarially fair scheme with defined contributions and occupational pensions; 2 . the vague centre-right counter-consensus of ODS, the Freedom Union, and some Christian Democrats referred to the necessity of introducing a "second pillar" of mandatory private insurance and further raising the retirement age.

The main elements of both concepts have remained to the present time. The "weak reform" introduced by the MoLSA is aimed at separating pension funds from the general revenue and administering them through a Public Social Insurance Company instead of the current Social Security Administration. Within PAYG system, notional personal accounts were intended to ensure a closer relation between pension benefits and both previous earnings and the number of contribution years. The current system of financing is to be complemented by revenues from the state budget, the latter presumably covering pension credits for non-contributory periods.

Under pressure of massive increase in early retirement (which in 2002-2003 reached a level of one-half of all new pensioners) the early retirement scheme was restricted so that the form of temporary reduced pension benefits was removed. This decision somewhat spoiled the long period of harmony that previously existed between the ČSSD-led government and the trade unions. While the trade unions supported the early retirement pension in its generous form and regarded it as a convenient means for attenuating unemployment, the government considered it a departure from the principle of solidarity and a misuse of an otherwise uniform pension system. Liberals also vehemently rejected early retirement, arguing that each early retiree costs twice as much as an unemployed person on benefits.

However, the main conflict is over compulsory savings in private funds and the establishment of a second mandatory fully-funded pillar that ensures equivalence between contributions and benefits. ČSSD have raised both defensive and offensive arguments. The former include the claim that "only the state can never go bank- 
rupt" and that "nobody can force people to save in private institutions". In their comments on the reforms implemented in Poland and Hungary, social democratic politicians stress their difficulties and later revisions. On the offensive side, social democrats speak, for instance, about the economic advantages of strong capital groupings that want to establish large private pension insurance funds for the sake of future profits.

Opinion polls witness decreasing satisfaction with pension system, in parallel with increasing expectations from the state. There is apparently no direct relationship between public opinion and concrete reform alternatives. Neither the financial experts who favour a fully-funded pillar, nor the experts from the MoLSA who prefer to stick to a reformed PAYG system employ public perceptions in their arguments. Politicians though are more attentive to the public's general inclinations. They are also aware of the huge economic, and thus also political, transaction costs of the system. This is probably the reason why no political party actively promotes any radical solution. This very prudence means that the necessary reduction in basic pension benefits, following a parametric adjustment of the current system according to a defined-contributions model, has not been stressed in the debate.

Data on the change of income position of pensioners' households are not consistent. On the one hand, the ratio of pension benefits to net wage has decreased systematically since 1991 by about ten percentage points until 2004 (see Figure 1 above). On the other hand, statistical income survey data report some decrease of income per capita between 1992 and 1996 relative to entire population, but an increase in 2002 on the level never reached before. The result was achieved despite the number of economically active members and pensioners slightly diminished while the number of "other" members (not receiving any important income) rose. The explanation that pensioners started to draw also other sources fails - the share of pension benefits even increased in fact (Table 2).

Also according to other information sources income packaging of pensioners' households has not changed so far, regarding involvement of additional resources. Survey data refer to some income (without specifying the amount) from old-age or life insurance in $7 \%$ of pensioners' households. ${ }^{6}$ However, following institutional data, while the number of people participating in the private old-age insurance system with state contribution is rising (it increased up to 3 million by mid-2005), their savings remain at about $2 \%$ of net earnings in the average only. Reality thus thwarted the initial intention: while the "liberal project" treated the public pension as a source of basic income only and envisaged that supplementary private schemes would eventually become the main source of the pensioner's livelihood, the customer public followed another direction.

Regarding the political affiliation of pensioners, it changed considerably between 1992 and 2002 (see Table 1). In 1996, ODS maintained its relative position, as did the Left Block. The ČSSD received huge support from the population and pensioners followed this trend, although with some delay. This continued in the 1998 byelections (not included in the table), when the ČSSD won. The swing of pensioners

6) The survey "Life in the Old Age" was made among 1,036 respondents 60 and older in May 2002 (Kuchařová, 2002). From the other side, for $70 \%$ of seniors old-age pension benefit was the only source of income in 2002 (Vohralíková and Rabušic, 2004). 
to the political left is documented by the results of 2002 elections, when already almost $60 \%$ of their votes were given to Social Democrats and Communists. While their tendency to support Social Democrats reached the average, their support for Communists kept its previous above-the-average figures.

\section{Future Pensioners - the Low or Middle Class?}

There is no return in time. Pensioners cannot establish their "emeritus" status as it existed in pre-war Czechoslovakia at least for professionals and state employees. They will mostly keep characteristics of social group - the question is which its position will be relative to the average and how much differentiated pensioners' income will be. Even at its lowest ladders, this social group is legitimated to be provided with resources on a decent level, following the principle of solidarity. Simultaneously, new chances of insurance and assets accumulation should allow to reach the middle and, even, the highest levels for a small part of pensioners.

Politics in pension area is twofold: to guarantee some basic (minimum or decent) pension benefits and to open the space (motivating or coercing) for individual activity. Political parties routinely present their "visions" in the area. Around the elections in 2002, the Freedom Union was the only party to advocate a fully-funded pillar, while ODS backed the idea of voluntary old-age insurance. On the political left the Social Democrats and the Communists supported only "weak reform" of the PAYG system and resolutely rejected compulsory savings. The Christian Democrats fluctuated between these two standpoints but being more inclined towards moderate reform and preservation of solidarity involved in the PAYG system.

\section{Scheme 1}

\section{Overview of Pension Reform Proposals Specified by Main Political Parties in 2005}

\begin{tabular}{|c|c|c|c|}
\hline $\begin{array}{l}\text { Social Democracy } \\
\text { (ČSSD) } \\
\text { NDC system }\end{array}$ & $\begin{array}{l}\text { Christian Democracy } \\
\text { (KDU-ČSL) } \\
\text { Partial opt-out }\end{array}$ & $\begin{array}{l}\text { Communist Party } \\
\text { (KSČM) } \\
\text { Parametrical } \\
\text { optimalization }\end{array}$ & $\begin{array}{l}\text { Civic Democratic Party } \\
\text { (ODS) } \\
\text { Flat rate pension } \\
\text { benefit }\end{array}$ \\
\hline $\begin{array}{l}\text { Notional individual } \\
\text { accounts (NDC) within } \\
\text { PAYG system, some } \\
\text { additional sources. } \\
\text { Guaranteed minimum } \\
\text { benefit relative to } \\
\text { subsistence minimum. } \\
\text { Statutory age } 65 \text { for } \\
\text { regular pensions but } \\
\text { higher for minimum } \\
\text { pensions for persons not } \\
\text { able to save enough. } \\
\text { Expected replacement } \\
\text { rate } 60 \% \text { ( } 48 \% \text { of NDC, } \\
12 \% \text { of additional } \\
\text { resources). }\end{array}$ & $\begin{array}{l}\text { Parametrical reform of } \\
\text { the PAYG system } \\
\left(1^{\text {st }} \text { pillar). Stronger }\right. \\
\text { equivalence of newly set } \\
\text { pensions. Increasing } \\
\text { statutory age up to } \\
65.3 \% \text { of personal } \\
\text { assessment base may be } \\
\text { shifted to funded account } \\
\text { provided the person will } \\
\text { contribute by other } 6 \% \\
\text { (2n pillar). If so, state } \\
\text { pension will be reduced } \\
\text { adequately. } 3^{\text {rd }} \text { pillar is } \\
\text { voluntary FF. }\end{array}$ & $\begin{array}{l}\text { Current PAYG system } \\
\text { considered sustainable up } \\
\text { to } 2023-2030 \text {, large } \\
\text { additional sources. } \\
\text { Increasing contribution } \\
\text { rate only in } 2040 \text { by } \\
3 \text { p.p. Statutory age up to } \\
65 \text {, but starting later. }\end{array}$ & $\begin{array}{l}\text { Reduction of the PAYG } \\
\text { system on flat rate } \\
\text { pension benefit at } 20 \% \\
\text { of the average wage } \\
\text { (=minimum guaranteed } \\
\text { state pension, valorised } \\
\text { by wage increase). } \\
\text { Increasing statutory age } \\
\text { finally up to } 71 \text {, no } \\
\text { early retirement. } 2 \text { p.p. } \\
\text { contributions will be } \\
\text { directed to parents' } \\
\text { pension benefits. } \\
\text { Otherwise private } \\
\text { schemes, but not } \\
\text { compulsory. }\end{array}$ \\
\hline
\end{tabular}

Source: Final report, 2005. 
The activity of political parties is not as clear and straightforward as the party ideologies might suggest. Vigorous rhetoric about the urgency of the problem has starkly contrasted with the limited activity, and alternative proposals for reform were nowhere near ready. Great effort towards clarification and quantification of main parties' ideas about pension reform was effectuated in 2005, when the "Team of Experts", where all main parties and the government were represented, and the "Executive Team" of experts led by CNB economist Vladimír Bezděk were established. The latter required parties to precise their variants and calculated their effect in the long run, better speaking only the mandatory part of the proposed reforms (Scheme 1).

It is near to impossible to draw a detailed picture of the living standard and its differentiation among pensioners or - better speaking - older people following the presented variants of pension reform. Increasing number of decisions will be in their hands: first and foremost, the decision regarding continuation of economic activity; next, the decision regarding partial (or even full) opt-out from the state system. The systems compared are only mandatory parts of old-age security and nobody can predict change in saving behaviour of people under various pension regimes.

The calculation of Bezděk's team uses only aggregated and averaged figures, such as "typical- income person" (Table 3). The best average benefits - in terms of the pension/wage ratio and gross replacement rate would be provided by current system that is, however, financially unsustainable producing cumulated deficit $43 \%$ of the GDP by 2050 (Final Report, 2005: 16). Such a "generous" system is proposed by communists who also want to increase contributions substantially and involve additional budget resources. The opposite ODS variant provides large discretion in households' decision and thus assumes strong and far-sighted personal involvement. Also Christian Democracy's proposal presumes decision to opt-out from the state system.

Another question is what will be the effect of intentions after they will be projected into the system and the system will shape behaviour of people some way. We can expect growing disparities but cannot say much about them, except the probability that the more discretion by opting-out from the state system, the greater inequality in pensioners' income. What is certain is that both poor and middle-class pensioners will appear, but uncertain are their proportion. The scarce data describing the period 1996-2002 witness some increase of inequality (see the Table 2) but do not indicate any change in dispersion of income in pensioners' households by education what is the main stratification axis of transforming Czech society. ${ }^{7)}$ This is related to the fact that inequality in replacement rates for different level of earnings belongs to the greatest among OECD countries. ${ }^{8}$

7) The distance of income per capita between pensioners' households headed by persons with elementary and tertiary education is 30 percentage points in both 1996 and 2002. Microcensus datasets do not allow much more as such variables as the last occupation and industry are missing for person in retirement.

8) For earnings at the double-average level, the net replacement rate is $35 \%$ in the Czech Republic what corresponds to liberal countries such as the UK, Ireland and US where mandatory system is not that crucial. In contrast, the same figure is for Belgium 42\%, Germany $67 \%$ and Austria $79 \%$ and OECD average 61\% (OECD, 2005). 
Even in well diversified systems with an uninterrupted tradition of saving for old age, outstanding scholars are able to speak but very generally about possible outcome in behavioural terms: "The changes in the generosity and targeting of the state pension system, combined with the changing nature of private pension provisions, are likely to affect peoples' saving and retirement decisions in different ways and different points of the income distribution... The most important group is those people who are or expect to be on low to middle incomes - who are at the boundary of the state and private systems. They will face clear incentives to work longer and retire later, but it is less clear whether, in aggregate, the system will encourage them to save more" (Banks and Blundell, 2005:52).

Both the ČSSD and ODS proposals include problems concerning the future income position of pensioners:

The social democratic proposal intends to strengthen the connection between pensions and lifelong earnings by means of notional accounts. This, however, is an illusory belief given the circumstances in which the total volume of funds for payments is to continually decrease while the minimum pension payment - guaranteed state pension - is to become more or less fixed. Thus the more likely outcome is that state pensions will be levelled towards the minimum, and the connection with earnings will consequently be further weakened - the higher the original earnings the more so. Indeed, the calculation shows that $65 \%$ of newly set pension benefits would fall below the poverty line eventually (Final Report, 2005: 47).

The civic democrats' idea relies on only a minimum and flat state pension and otherwise emphasizes "individual retirement insurance, investments and savings" (Blue Chance, 2003: 22). This vision, however, has some unrealistic expectations, in particular concerning the orientation towards long-term savings and investments. This is documented by the current use of resources so far collected: they are used as additional income source in retirement age only in less than one per cent of cases and the rest as mid-term savings cashed to date (72\%) or as surrenders (24\%) (NSRP, 2005:8).

Although no radical reform is envisaged in the Czech Republic, even partial diversification of resources for old age apparently takes time. Consequently, no delay in the process is desirable. However, after accomplishment of the Bezděk's team work, little activity followed. The consensus is near to be achieved only about further rise of the statutory age of retirement after 2012 (when the limit 63 should be reached) gradually up to 65 in 2031. Communists want to postpone the further rise between 2031 and 2036. The state will remain the main payer of pension benefits. In addition, the state should also support supplementary old-age insurance and life insurance by tax credits or contributions.

\section{Discussion and Conclusion: System Credibility and the Prospect of Time}

Old-age protection is an inherently conflictfull issue built into the welfare state. In a static cross-section, there is a conflict between the "cost-containment interests" of contributors, taxpayers and business investors and the "needs-satisfaction interests" of current and future pensioners (terminology of Jens Alber, 1996:16-18). If old-age security is exclusively a matter of redistribution handled by the state, it re- 
legates pensioners to the status of mere recipients of social benefits and pits them implicitly against the taxable active population. In the long run, pensioners and all persons approaching retirement will likely support programmes of growing redistribution, with all its adverse consequences. ${ }^{9)}$

Throughout life cycle dynamics, there is a conflict between current and deferred consumption. Two trends interweave in Czech society: the communist legacy and a modern, mass consumption society. Beginning in the late 1940s, the communist regime systematically eradicated peoples' orientation towards the future. Similarly, as it deprived people of all their previous assets, it also destroyed forms of long-term planning that were previously rooted in society, such as the promotion of entrepreneurship, the nurturing of family lines, and the accumulation of assets. In addition, since the early 1990s, the invasion of mass consumption even strengthened this legacy by opening access to products inaccessible in the communist shortage economy - high quality cars, electronics, housing appliances, etc.

In a modern society, three goods are particularly worthy investments for the future of an individual or family: education, housing and old-age assets. Family savings are largely directed into building saving plans. In contrast to the growing level of household indebtedness, old-age savings remain at a low level. The MoLSA report states that "the participation in the state-subsidized supplementary pension insurance scheme is relatively high (almost 3 million participants), however, the assets held by pension funds are still relatively low (only $3.7 \%$ of GDP). Only about one percent of participants to whom so far benefits were granted are represented by pension beneficiaries. Currently, as part of private life insurance schemes, some 3 million contracts have been entered into and the total value of technical reserves of all life insurance products accounts for 5.6\% of GDP" (NSRP, 2005:6).

Indeed, there are wide disparities between countries in the size of their pension funds as a per cent of GDP: in 2001, it was 3\% in Germany, 4\% in Italy, 6\% in Belgium and Sweden, while $66 \%$ in the UK and even $105 \%$ in the Netherlands and 114\% in Switzerland (OECD 2005a:24). Surprisingly, even in countries where public systems dominate, the credibility of the pension system is problematic. Summarizing the OECD survey, Timothy Besley and Andrea Prat (2005) pointed out that there is little confidence in public pension systems, including countries with high fertility rates, such as France. In contrast, the readiness to opt-out from the PAYG system was found to be quite high in the survey. ${ }^{10)}$

To support private old-age investment, the World Bank recommends “... to use both tax incentives and compulsion. The case for compulsory provision is based on the need to overcome the myopic behaviour of a large minority of workers and to protect society from those who make inadequate provision for their old age."

\footnotetext{
9) The standard statistics on the average wage and the average pension benefit in the Czech Republic are not self-evident. In western countries, pensioners' incomes are usually comprised of many sources and thus can be grasped in total only through income surveys (OECD, 2001). The wage/pension ratio - an indicator closely watched in the CR - therefore, can hardly be compared with other countries.

10) See Boeri, Bôrsch-Supan and Tabellini (2001). The survey was collected in France, Germany, Italy and Spain.
} 
Exempted from compulsory participation should be only “... the very young (under 25), the very old (over the normal retirement age), the very poor (those earning less than $40 \%$ of the average wage) and the self-employed." At the same time, however, funds should be under strict control, and the regulatory framework needs to be robust and effective (Vittas, 2002: 36-37).

Indeed, in the myopic behaviour regarding old-age security, various factors and reasons interact and accumulate, including the acceleration of mass consumption and the accompanying indebtedness. In addition, short electoral periods lead political parties to avoid "unpopular measures," thus dimming the prospects for long-term reforms in democratic conditions. As in any other single pillar, reliance on private funding cannot be the only way to solve pension problems. All three major actors the state, market and the family - should be mobilized. The PAYG system should be supported also by bringing children back into the system.

Before the welfare state developed, children were raised in part to guarantee the well-being of their parents in old age. In the current system, the number of children that older people have matters only in determining women's retirement age. If the welfare state stresses intergenerational solidarity, it neglects intergenerational reproduction. This contributes to the state of affairs in which the values people express towards raising children sharply contrast with the real reproductive behaviour of the populace. The Czechs belong to the first nations in ranking the value of children, according to the European Values Survey. However, the Czech Republic displays the lowest fertility rate among European countries, unlike "child-low-value" countries, such as Sweden and the Netherlands.

Proposals aimed at acknowledging the value of children in the pension system "pay by money or children" - might be thus of crucial importance. James Hyzl et al. (2004) have proposed that the pension system recognize the "production of future contributors." They argue that "...PAYG is not an insurance system through which we save for retirement. PAYG is only a clearing center where the working (children) pay for the retirees (parents). The contribution is not money but children ... Thus the solution to fixing the PAYG is to not pay benefits to non-contributors ... The investment can be money or children (when it comes to pensions both are of equal value), or a combination of both but the investment must be made. Without investment there is no benefit and the size of benefit equals to the size of investment" (Hyzl et al., 2004:5-6).

Another way to recognize children in the pension system, though far from being a core idea, has been proposed by ODS' pension reform. As a supplementary scheme, pensioners would receive a certain percentage of the gross wages of their children. The plan assumes that from a contribution rate of $20 \%$, two percentage points would be directed to their own parents' pension benefits. The rationale behind this is to introduce to the pension system - which depends on the demographical behaviour of the population - a clear link to the demographical behaviour of the individual contributor. Such a plan would support social justice, traditional family ties as well as a more balanced demographic structure of the population (Final Report, 2005: 104).

Last, but not least, people's increasing longevity should at least partly be reflected in the duration of working life. The retention of older people in employment is a matter of crucial importance, and has been a focus of the OECD, EU and other 
institutions for the last several years. ${ }^{11)}$ Working longer in life is thus becoming a necessity, which is challenging the customary attitudes and behaviour of the Czechs. The prevailing opinion of the population is that the current arrangement regarding the statutory retirement age should not be changed (Vidovičová, 2005). As for employers, when a company makes staff reductions, older employees are still the first to be laid-off and the last to be re-employed if a vacancy appears. So far, the general effort of populace to retire as soon as possible has not been successfully challenged.

In the 2006 elections, the pensioner vote given to both leftist parties in absolute figures remained about the same, but it substantially increased in relative terms among leftist voters, due to the overall loss of votes on the left. ${ }^{12)}$ The outlook is thus ambivalent. In any case, the following trend - producing a vicious circle might be a warning: The longer that the retirement age will not increase further than to only the currently established limit, and the less older people will be motivated to retire later, greater the share of the population that pensioners will constitute. Consequently, greater relative support may be given to parties who oppose any substantial reform. Increasing transfers from the economically active part of the population will be unfavourable for the family and fertility. While no reform will affect today's pensioners, their vote affects the status of future pensioners - whether they will belong among the ranks of the poor or the middle-class.

11) See the OECD project "Ageing and Employment Policies" headed by Raymond Torres. The project has involved 21 countries, and 18 country reports have been published so far. The Czech study was published in 2004 (OECD, 2004). See also the European Commission, 2006.

12) The SC\&C and SPSS Exit Poll commissioned by Czech TV. See www.scac.cz for further information. 
Table 1

Vote for the Political Parties in Parliamentary Elections by Social Category (in \%)

\begin{tabular}{|l|r|r|r|r|r|r|r|}
\hline Political party or coalition & $\begin{array}{c}\text { Profes- } \\
\text { sionals }\end{array}$ & $\begin{array}{c}\text { Routine } \\
\text { non- } \\
\text { manual }\end{array}$ & $\begin{array}{c}\text { Self- } \\
\text { emp- } \\
\text { loyed }\end{array}$ & $\begin{array}{c}\text { Manual } \\
\text { wor- } \\
\text { kers }\end{array}$ & $\begin{array}{c}\text { Pensi- } \\
\text { oners }\end{array}$ & Total & $\begin{array}{c}\text { Ratio } \\
\text { pensi- } \\
\text { oners/ } \\
\text { total }\end{array}$ \\
\hline 1992: & & & & & & & \\
Civic Democratic Party (ODS) & 31.7 & 33.2 & 42.6 & 22.8 & 27.1 & 28.9 & 93.8 \\
Social Democracy (ČSSD) & 7.2 & 7.3 & 2.4 & 7.1 & 6.2 & 6.6 & 93.9 \\
Left Block (LB) & 13.8 & 14.2 & 5.4 & 13.2 & 18.5 & 14.1 & 131.2 \\
Christian Democracy (KDU-ČSL) & 6.4 & 5.1 & 1.8 & 6.1 & 9.3 & 6.3 & 147.6 \\
Republicans (SPR-RSČ) & 1.9 & 5.2 & 6.2 & 9.5 & 1.7 & 5.6 & 30.4 \\
Civic Democratic Alliance (ODA) & 12.9 & 7.9 & 7.0 & 3.4 & 4.1 & 5.9 & 69.5 \\
Pensioners for Security (HDŽJ) & 1.1 & 1.2 & 0.2 & 1.9 & 12.9 & 4.0 & 322.5 \\
Other parties & 25.0 & 25.9 & 34.4 & 36.0 & 20.2 & 28.6 & 70.6 \\
Total & 100.0 & 100.0 & 100.0 & 100.0 & 100.0 & 100.0 & 100.0 \\
\hline 1996: & & & & & & & \\
Civic Democratic Party (ODS) & 36.3 & 29.8 & 44.8 & 18.9 & 27.5 & 29.0 & 94.8 \\
Social Democracy (ČSSD) & 22.3 & 29.9 & 17.7 & 35.0 & 21.4 & 26.7 & 80.1 \\
Left Block (LB) & 9.4 & 10.2 & 5.5 & 11.7 & 19.5 & 12.3 & 158.5 \\
Christian Democracy (KDU-ČSL) & 9.8 & 6.2 & 4.7 & 8.2 & 10.4 & 7.9 & 131.6 \\
Republicans (SPR-RSČ) & 1.9 & 8.2 & 9.7 & 12.8 & 3.9 & 7.9 & 49.4 \\
Civic Democratic Alliance (ODA) & 11.8 & 7.1 & 8.7 & 3.8 & 3.3 & 5.9 & 55.9 \\
Pensioners for Security (HDŽJ) & 0.3 & 1.3 & 0.9 & 2.1 & 8.9 & 3.3 & 269.7 \\
Other parties & 8.2 & 7.3 & 8.0 & 7.5 & 5.1 & 7.0 & 72.9 \\
Total & 100.0 & 100.0 & 100.0 & 100.0 & 100.0 & 100.0 & 100.0 \\
\hline 2002: & & & & & & & \\
Civic Democratic Party (ODS) & 21.6 & 27.0 & 15.1 & 44.5 & 19.1 & 24.5 & 78.0 \\
Social Democracy (ČSSD) & 39.3 & 31.4 & 32.5 & 20.6 & 30.2 & 30.2 & 100.0 \\
Coalition & 12.6 & 16.5 & 10.4 & 12.6 & 14.4 & 14.3 & 100.7 \\
Communists (KSČM) & 14.6 & 12.7 & 27.4 & 10.0 & 28.3 & 18.5 & 153.0 \\
Other parties & 12.0 & 12.5 & 14.7 & 12.3 & 8.0 & 12.5 & 64.0 \\
Total & 100.0 & 100.0 & 100.0 & 100.0 & 100.0 & 100.0 & 100.0 \\
\hline
\end{tabular}

Source: Exit Polls carried out by INFAS and FACTUM for Czechoslovak TV in 1992, by INFAS and SC\&C for Czech TV in 1996, and by SC\&C for Czech TV in 2002. 
Table 2

Pensioners' Households and Their Per Capita Income in 1988-2002 (CZK yearly and per cent)

\begin{tabular}{|l|r|r|r|r|r|r|r|r|}
\hline & \multicolumn{5}{|c|}{ Averages } & \multicolumn{4}{c|}{ Per cent } \\
\hline & 1988 & 1992 & 1996 & 2002 & 1988 & 1992 & 1996 & 2002 \\
\hline Households: & & & & & & & & \\
No of persons & 1.62 & 1.71 & 1.73 & 1.72 & 100.0 & 100.0 & 100.0 & 100.0 \\
EA & 0.17 & 0.16 & 0.17 & 0.14 & 10.5 & 9.4 & 9.8 & 8.1 \\
Children & 0.05 & 0.07 & 0.08 & 0.08 & 3.1 & 4.1 & 4.6 & 4.7 \\
Pensioners & 1.35 & 1.46 & 1.44 & 1.42 & 83.3 & 85.4 & 83.2 & 82.6 \\
Other & 0.05 & 0.02 & 0.04 & 0.08 & 3.1 & 1.2 & 2.3 & 4.7 \\
\hline Net income: & & & & & & & & \\
Total & 19427 & 30169 & 55096 & 84361 & 100.0 & 100.0 & 100.0 & 100.0 \\
Earned & 3400 & 3828 & 7171 & 9764 & 17.5 & 12.7 & 13.0 & 11.6 \\
Pension benefits & 15643 & 23120 & 44336 & 69827 & 80.5 & 76.6 & 80.5 & 82.8 \\
Transfer income & 153 & 2780 & 1086 & 2335 & 0.8 & 9.2 & 2.0 & 2.8 \\
Other & 230 & 441 & 2503 & 2435 & 1.2 & 1.5 & 4.5 & 2.9 \\
\hline Decile ratio of & & & & & 2.26 & 1.67 & 1.73 & 1.81 \\
distribution of total & & & & & & & & \\
net income & & & & & & & & \\
Ratio of pensioners & & & & & 87.1 & 89.5 & 86.8 & 90.7 \\
income to the & & & & & & & & \\
average & & & & & & & & \\
\hline
\end{tabular}

Source: Microcensus surveys (source publications of the CSO, the decile ratio computed by the author). 
Table 3

Effects of Pension Reforms Featured by Main Political Parties in 2005-2050 (in \%)

\begin{tabular}{|c|c|c|c|c|c|c|}
\hline & 2005 & 2010 & 2020 & 2030 & 2040 & 2050 \\
\hline \multicolumn{7}{|l|}{ Contributions in percent gross wage } \\
\hline Basic variant - no change & 28.0 & 28.0 & 28.0 & 28.0 & 28.0 & 28.0 \\
\hline Social Democracy (ČSSD) & 28.0 & 29.6 & 29.6 & 29.6 & 29.6 & 29.6 \\
\hline Christian Democracy (KDU-ČSL) & & - & & - & - & \\
\hline Communists (KSČM) & 28.0 & 28.0 & 29.6 & 29.6 & 33.6 & 33.6 \\
\hline Civic Democratic Party (ODS) & 28.0 & 20.0 & 20.0 & 20.0 & 20.0 & 20.0 \\
\hline \multicolumn{7}{|l|}{ Ratio of pension to gross wage } \\
\hline Basic variant - no change & 42.1 & 39.7 & 37.4 & 37.0 & 37.9 & 38.2 \\
\hline Social Democracy (ČSSD) & 42.1 & 40.6 & 39.5 & 39.9 & 40.0 & 36.8 \\
\hline Christian Democracy (KDU-ČSL) & 42.1 & 37.7 & 32.0 & 29.8 & 30.4 & 30.5 \\
\hline Communists (KSČM) & 42.1 & 39.7 & 37.5 & 37.7 & 38.8 & 40.1 \\
\hline Civic Democratic Party (ODS) & 42.1 & 37.7 & 30.9 & 26.1 & 22.7 & 20.7 \\
\hline \multicolumn{7}{|l|}{ Gross replacement rate man/woman) } \\
\hline Basic variant - no change & $65 / 82$ & $62 / 77$ & $58 / 67$ & $57 / 63$ & $57 / 63$ & $57 / 63$ \\
\hline Social Democracy (ČSSD) & $65 / 82$ & $63 / 77$ & $62 / 68$ & $61 / 60$ & $55 / 54$ & $50 / 48$ \\
\hline Christian Democracy (KDU-ČSL) & & & & & - & \\
\hline Communists (KSČM) & $65 / 82$ & $62 / 77$ & $58 / 67$ & $57 / 63$ & $51 / 61$ & $51 / 52$ \\
\hline Civic Democratic Party (ODS) & $65 / 82$ & $62 / 77$ & $42 / 49$ & $29 / 30$ & - & \\
\hline
\end{tabular}

Source: Final Report, 2005.

\section{References}

Alber, J. (1996), Towards a Comparison of Recent Welfare State Developments in Germany and the United States. Quoted in Müller (1999).

Banks, J., Blundell, R. (2005), Private Pension Arrangements and Retirement in Britain. Fiscal Studies 26, pp. 35-53.

Besley, T., Prat, A. (2005), Credible Pensions. Fiscal Studies 26, pp. 119-135.

"Blue Chance. Basic Theses of Financial Politics of the ODS". Edition Blue Chance No. 1. Prague: ODS (in Czech).

Boeri, T., Börsch-Supan, A., Tabellini, G. (2001), Would You Like to Shrink the Welfare State? The opinions of European citizens. Economic Policy 32, pp. 9-50.

"Concept (2000) of Further Continuation of Pension Reform". Prague: Ministry of Labour and Social Affairs (in Czech).

"Concept (2003) for the Reform of Public Finance". Prague: Ministry of Finance (in Czech).

European Commission (2006), The Impact of Ageing on Public Expenditure: Projections for the EU25 Member States on Pensions, Health Care, Long-Term Care, Education and Unemployment Transfers (2004-2050). Special Report No. 1.

"Facts (1997) about Social Situation in the Czech Republic". Prague: Czech Statistical Office (in Czech).

"Final Report (2005) Pension Reform: Possibilities and Outlook. Executive Team for Preparation the Background for Decision about Pension Reform in the CR". Prague: Office of the Government (in Czech). 
Hyzl, J., Rusnok, J., Řezníček, T., Kulhavý, M. (2004), "Sustainable Pension Solutions (An Innovative Approach)". Praha: ING CR and SR. http://www.ing.cz/cz/o_ing/INGnavrhpenzijnireformy.pdf.

ILO (2002), "Pension Reform in Central and Eastern Europe". Vol. 1. Restructuring with Privatization: Case Studies of Hungary and Poland. Budapest: International Labour Office.

Kočišová, J. et al. (1997), "Analysis of International Experience for use of Transformation of Pension Insurance". Final Report of the Project. Prague: Czechoslovak Commercial Bank (in Czech).

Kuchařová, V. (2002), "Life in the Old Age”. Report of the empirical survey. Prague: RILSA (in Czech).

Müller, K. (1999), The Political Economy of Pension Reform in Central-Eastern Europe. Cheltenham, UK and Northampton, MA: Edward Elgar.

NSRP (2005), "National Strategy Report on Adequate and Sustainable Pensions (NSRP)". Prague: Ministry of Labour and Social Affairs.

OECD (2001), Ageing and Income. Financial Resources and Retirement in 9 OECD Countries. Paris: OECD. (2004), Ageing and Employment Policies. Czech Republic. Paris: OECD. (2005a), Ageing and Pension System Reform. Implication for Financial Markets and Economic Policies. Paris: OECD. (2005b), Employment Outlook 2005. Paris: OECD.

Polívka, M. (1998), "Debate on Social Laws". Research Papers of the START Foundation (in Czech).

"Proposal (2003) of Main Principles of Further Continuation of Pension Reform". Prague: Ministry of Labour and Social Affairs (in Czech).

Večerník, J. (1999), "The Middle Classes in the Czech Reforms: The Interplay between Policies and Social Stratification". Communist and Post-Communist Studies 32, pp. 397-416. (2004), Who Is Poor in the Czech Republic? The Changing Structure and Faces of Poverty after 1989. Czech Sociological Review, 40, pp. 605-618.

Vidovičová, L., Rabušic, L. (2005), "Age Discrimination - Ageism. Introduction to the Theory and Incidence of Discriminatory Approaches in Selected Areas Focussing on the Labour Market". Prague: RILSA (in Czech).

Vittas, D. (2002), "Policies to Promote Saving for Retirement: a Synthetic Overview". Policy Research Working Paper No. 2801. Washington, D.C.: The World Bank.

Vohralíková, L., Rabušic, L. (2004), “Czech Seniors Yesterday, Today and Tomorrow”. Prague: RILSA (in Czech).

World Bank (1994), Averting the Old Age Crisis: Policies to Protect the Old and Promote Growth. Washington: The World Bank. 